\title{
ON SYMBOLON AND SYNTHËMA in the Platonic Theology of Proclus
}

\author{
DMITRY KURDYBAYLO \\ Russian Christian Academy for the Humanities; \\ Saint Petersburg State University; \\ The Herzen State Pedagogical University of Russia \\ theoreo@yandex.ru
}

\begin{abstract}
Many recent studies propose that symbolon and synthemma are synonymous in the writings of Proclus. However, his Platonic Theology contains reliable evidence to put this opinion to doubt. The goal of this research is to determine the meaning of both terms from the contexts of their usage, engaging the textual analysis and the following philosophical reconstruction. As distinguished from a symbol, a synthèma has substantial nature, is stable and remains invariable when is discovered at different levels of the ontological hierarchy. In the Platonic Theology, a symbol is often considered in terms of the hierarchic level, where it appears: in the material world, it is corporeal; among numbers, it is ontologically irrelevant, the intelligible realm contains its proper symbols as well. A significant difference between symbolon and synthēma is related to the dialectics of participation: synthēma in an object keeps it on an unparticipated level, while a symbol implies further participation to a symbolic object. Finally, a synthēma is described as "disseminated," "planted," or in any other way hidden in the being; while a symbol is "discovered," or found in the being, therefore synthemma may be considered an inner kernel of what is discovered as a symbol, and a symbol - as an outward expression of a synthēma. Such understanding of these terms agrees with both exegetical and theurgic contexts in Proclus' Platonic Theology.

KeywORDS: Proclus, Theologia platonica, Platonic Theology, Neoplatonism, symbol, synthēma, theurgy, ontology, myth.

* The research was carried out at Russian Christian Academy for the Humanities (Saint Petersburg) with the financial support of Russian Science Foundation, project 17-7810061.
\end{abstract}

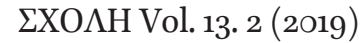

www.nsu.ru/classics/schole
(C) Dmitry Kurdybaylo, 2019

DOI:10.25205/1995-4328-2019-13-2-463-485 
Neoplatonic philosophy of language, the theory of reference and signification, and their ontologic status have attracted much scholarly interest during past decades. The researches of Robbert van den Berg (2008), Peter Struck (2004), and Sara Rappe (2007) provide an extensive elaboration of themes, initially exposed by John Dillon (1975), Jean Trouillard (1981), and Gregory Shaw (1995).

One of the essential Neoplatonic notions in this field is $\sigma \dot{0} \mu \beta 0 \lambda \circ v$, "a symbol." However, another term, $\sigma \dot{v} \vartheta \eta \mu \alpha$ has a similar meaning. Many scholars and translators of Proclus' works do not distinguish these notions and easily interchange them. ${ }^{1}$ Just a few researchers tried to find a distinction between symbolon and synthèma in Proclus' writings. In 1981, Jean Trouillard introduced the basic considerations related to this problem (Trouillard 1981), and in 1985 Rosa Loredano Cardullo undertook a profound examination of all the places, where terms symbolon, synthèma, and eikōn are mentioned in Proclus' commentary on Plato's Republic (Cardullo 1985). ${ }^{2}$ Unfortunately, I could not find any further examinations of other Proclean texts done in the same way. However, the study of R.L. Cardullo provided very promising results, and other writings of Proclus contain much relevant material.

Using the analytic tools of the TLG, one can find at least 238 occurrences of symbolon in all extant works of Proclus. Among them, 65 occurrences are located in the commentary in Rem publicam; 66 in the commentary in Timaeum; 35 in the commentary in Parmenidem, and at least 30 in the Theologia Platonica. Other writings contain 42 other mentions, i.e. less than ${ }^{1} / 5$. A half less frequent term is synthèma with 120 mentions distributed between Proclean writings in a similar proportion. After the studies of the semantics of symbolon and synthema in Proclean commentaries in Timaeum and in Cratylum, published recently, ${ }^{3}$ this work continues the research addressing the Theologia Platonica (referenced as TP hereinafter). Despite less frequent usage of symbolon, the contents of the TP provides

\footnotetext{
${ }^{1}$ Sheppard 1980, 146; Struck 2004, 234; Rappe 2007, 11-12 and 176-178; Petroff 2013, 217. See also the translations of Proclus by Festugière 1966-1968, and Tarrant, Duvick 2014. In the notes to their translation, D. Saffrey and L.G. Westerink (1968-1997) mention that $\sigma \dot{u} \mu \beta 0 \lambda$ ov can be distinguished from $\sigma \dot{v} \theta \eta \mu \alpha$ (vol. 2, p. 114, n. 5) and can be translated using different terms (vol. 4, p. 131, n. 7). However, their translation contains 27 places, where $\sigma \dot{v} v \theta \eta \mu \alpha$ is rendered as "symbole," once as "caractère distinctif" (6.78.29), and once as "la marque unique" (6.24.8-9). In other words, $\sigma \dot{v} \vartheta \eta \mu \alpha$ appears to be almost not distinguished from $\sigma \dot{\nu} \mu \beta 0 \lambda$ ov in the French version.

${ }^{2}$ It should be mentioned that relatively old translations such as Taylor's (1995) and Turolla's (1957) render $\sigma \dot{u} \mu \beta 0 \lambda$ ov and $\sigma \dot{v} v \theta \eta \mu \alpha$ with corresponding different terms (more or less stable over the whole text).

${ }^{3}$ See Kurdybaylo 2018 and 2019.
} 
a much deeper insight into the philosophy of Proclus, than what can be concluded from the previously studied commentaries on Plato's dialogues. Being one of the latest Proclean writings, the TP reveals the most intricate details of his semantics and dialectics.

The main method employed in this study is the context analysis, which is used to restore the meaning of symbolon and synthēma from their original textual environment, following the basic approach introduced by Émile Benveniste (Benveniste 1966, 307). After the search of relevant contexts, they are classified and ordered. Below all the gathered evidence will be described and analysed. The majority of conclusions will be made according to the $T P$ text only, i.e. independently of other Proclean writings. This is intended to provide the further possibility to compare argumentation of Proclus in his different works, and if it appears possible, to trace the evolution of his views.

\section{Myth and symbol as a means to express theological knowledge}

In the first book of the $T P$, Proclus compares different ways to express the theological knowledge, and promises that during all the following discussion he will "prefer the clear, distinct, and simple [narration] to the contraries of these," while "the contraries" are "delivered through symbols ( $\delta \dot{\alpha} \sigma \nu \mu \beta \hat{\jmath} \lambda \omega \nu)$... and images ( $\delta \imath^{\prime}$

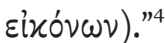

The symbolic way of speaking as attributed firstly to Plato, who is said to "teach us mystic doctrines of divine natures" using four modes: an ecstatic ( $\dot{v} v \theta \varepsilon \alpha \sigma \tau i x \omega \varsigma$ ), a dialectical, a symbolical, and via an ascent from images ( $\dot{\alpha} \pi \dot{\partial} \tau \hat{\omega} \nu$

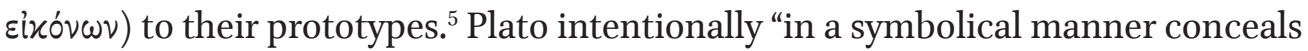
the truth about divine natures," ${ }^{, 6}$ thus making his thought understandable only to his closest disciples. ${ }^{7}$

Each way of speaking is used for a different purpose: the symbolic (or mythic),

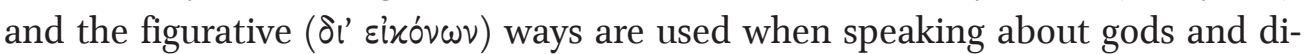
vine things. An expression of human's own thoughts is performed "according to

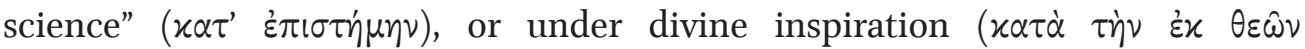

${ }^{4}$ TP 1.9.2O-24, hereinafter the Greek text is cited from: Saffrey, Westerink 1968-1997. English translation is based on the Thomas Taylor's edition (1995) with my significant modifications taking in account modern French (by Saffrey and Westerink) and Italian (Casaglia, Linguiti 2007; Turolla 1957) translations. Taylor's translation is referenced below as $\operatorname{Tr}$. with a page number. This quotation goes from Tr. 53. For more details on the passage cited see: Sheppard 2014, 62.

${ }^{5}$ TP 1.17.18-24, Tr. 59. See also note ad loc. in: Saffrey, Westerink vol. 1, p. 132, n. 4.

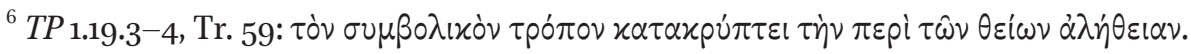

${ }^{7}$ TP 1.19.4-5, Tr. 59 . 
$\dot{\varepsilon} \pi i \pi v o(\alpha v) .{ }^{8}$ Proclus notes that the mythic or symbolic way pertains to Orphic tradition, the figurative one - to Pythagorean, and the "scientific" ( $\left.\varkappa \alpha \tau^{\prime} \varepsilon \dot{\varepsilon} \tau \tau \tau^{\prime} \mu \eta \nu\right)$ way pertains to Platonists. ${ }^{9}$

Symbols and myths are considered inferior when compared with a "philosophical" type of narrative, an example of which one can find in Plato's Republic. The drawback of symbolism is that it shows "intelligible with the means of sensible, immaterial with the material, whole with partial, and what is true with images that have false being." ${ }^{10}$

The figurative language of symbol and myth may be confusing: what is asserted symbolically, may be denied by a more precise discourse. For instance, a myth (e.g., Diotima's narrative in the Symposium) speaks of a god's birth when a "dialectical discourse" ( $\delta 1 \alpha \lambda \varepsilon \kappa \tau \mid \kappa \varepsilon v o \mu \varepsilon \dot{v \omega} \omega)$ finds all gods being unbegotten." This latter way is called "intellectual and not mystic," it reveals that what symbolically is described as a god's genealogy, actually is a relation to "unspeakable causes" of an ever-unbegotten deity. ${ }^{12}$

Nevertheless, there is a more or less stable correspondence between the intellectual realm and its sensual revelations, ${ }^{13}$ thus making up a kind of semantic system, which one may call a language of symbols. Proclus develops this idea into a theory of divine names. He mentions it very briefly in the TP book 1, chapter 29, perhaps, because a detailed discussion was already given in his commentary to the Cratylus of Plato. ${ }^{14}$

The difference between a myth and a symbol is quite clear in the TP: many symbols are used to express theological knowledge in a composite narrative, which is considered a myth as a whole. Thus, the mythological language is naturally a language of symbols. However, not every expression that is built of symbols is necessary a myth.

${ }^{8}$ TP 1.20.1-5, Tr. 6 o.

${ }^{9}$ TP 1.20.7-25, Tr. 6o.

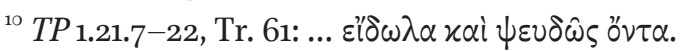

${ }^{11}$ For other examples, see references in Saffrey, Westerink 1968, vol. 1, pp. 137-138, n. 2.

${ }^{12} T P$ 1.120.22-121.14, Tr. 123. Noticeably, this pattern was introduced as early as by the times of Plotinus, who tried to reconcile the origin of the universe described in Plato's Timaeus with a traditional ancient view of the universe's eternal being, with no beginning or end (in addition to Enn. II.1, a treatise dedicated to this question, see also: Enn. IV.3.9.15-19, and VI.2.7.36-41).

${ }^{13}$ Cf. TP 1.124.12-20, Tr. 125 .

${ }^{14}$ See: Tarrant, Duvick 2014; van den Berg 2008. 


\section{Symbols in theurgy}

For Proclus, theurgy "awakes the divine presence" with the use of material symbols. ${ }^{15}$ Such theurgic symbols make up a group that differs (at some extent) from "exegetical" symbols, i.e. those discovered in a written text, like Plato's dialogues, for instance. The most important difference is obvious: theurgic symbols are material objects, while the exegetical ones are mere literal descriptions of such objects. ${ }^{16}$ The former may influence a human both physically and intellectually when the latter is capable of an intellectual influence only.

However, Proclus does not compare theurgic symbols with exegetical ones, but gives another surprising pair:

As the theurgic art through certain $\mathrm{sy} \mathrm{m} \mathrm{bols} \mathrm{calls} \mathrm{forth} \mathrm{the} \mathrm{unenvying} \mathrm{goodness}$ of the Gods into the illumination of artificial statues, thus also the intellectual science

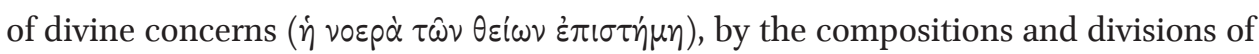
sounds, reveals the concealed essence of the Gods. ${ }^{17}$

The "intellectual science" that operates with "the compositions and divisions of sounds," probably, is that "dialectic discourse," which Proclus finds the most appropriate to the invisible nature of gods, and which excels symbols and myths. But if we try to reflect this intellectual revelation of divine nature into the material realm, the result will be an illuminated and deified theurgic symbol. Naturally, an exegetical symbol should be placed between these two extremes: it is more intellectual than a material object, but is less intellectual than what is expressed "dialectically." However, it does not mean that every myth or every exegetical symbol is based on real material symbols. Proclus emphasizes that our intellect is capable of grasping "divine natures" and verbally expressing them via "images" in a symbolic manner: "representing that, which is void of composition in them ( $\tau$ ò $\dot{\alpha} \sigma \dot{v} v \theta \varepsilon \tau \sigma \nu \alpha \dot{\tau} \tau \hat{\omega} v)$, through composition; that which is simple, through variety; and that which is united, through multitude."18

\section{Exegetical symbols}

As far as a theurgic symbol is a material object, and an exegetic symbol also has primarily material attributes, one can expect that any particular symbol should

\footnotetext{
${ }^{15}$ Trouillard 1972, 175: « La théurgie est un symbolisme opératoire destiné à éveiller la présence divine».

${ }^{16}$ Despite different nature, their effect may be equal: "certain constructions in language, from individual words to whole poetic scenes, operate precisely like the symbolic tokens in the theurgic ritual" (emphasis by P. Struck 2004, p. 235, cf. also p. 250).

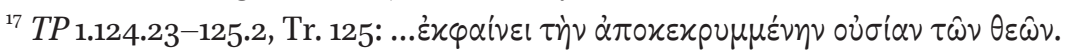

${ }^{18} T P$ 1.124.19-20, Tr. 125 .
} 
pertain to the material world. There is a wide range of relevant examples that support this assumption.

The "plain where truth stands" in the Phaedrus $\left(248 \mathrm{~b}_{5}-\mathrm{c} 4\right)^{19}$ is interpreted by Proclus down to the smallest details. He starts his explanation:

The "plain of truth" is intellectually exposed to intelligible light, and is splendid with the illuminations that proceed from there. ... The "meadow" is the prolific power of life, and of all kinds of logoi, is the comprehension ( $\pi \varepsilon p 10 \times \eta$ ') of the first efficient causes of life, and is the cause of the variety, and generation of forms. For the meadows also which are here are productive of all kinds of forms and logoi, and bear water which

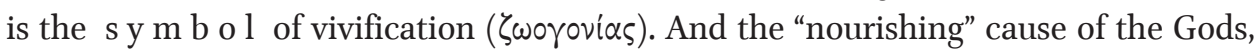
is a certain intelligible union, comprehending in itself the whole perfection of the Gods... ${ }^{20}$

Noticeably, Proclus applies the term "symbol" only to water that pertains to "the meadows, which are here," i.e. the material water and meadows. On the contrary, neither intellectual "plain," nor "meadow" nor any of their attributes are

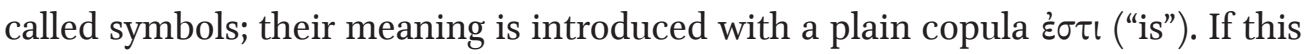
wording is not accidental, then Proclus avoids applying "symbol" to intellectual and intelligible objects.

Material objects mentioned in ancient Greek myths, such as of Homer's epic, can also be symbols subject to interpretation. For instance, Proclus writes regarding the mythological history of Cronus: "bonds and sections are symbols of communion and separation, and each is the offspring of the same divine mythology ( $\theta \varepsilon \circ \mu \nu \theta i \alpha \varsigma) .{ }^{21}$ In another place, the same bonds are "the symbol of the connective order of the gods, since everything, which is bound ( $\pi \hat{\alpha} \nu \tau \dot{\partial} \delta \varepsilon \delta \varepsilon \mu \varepsilon$ vov), is connect-

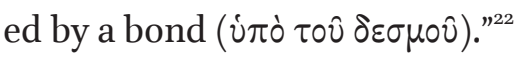

Another mythological symbol is borrowed from the Protagoras, where the

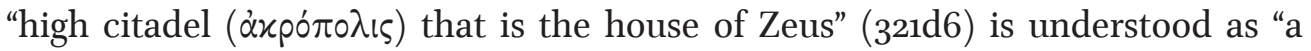
symbol of intellectual circulation, and of the highest summit of Olympus."23

The attributes of three Fates ( $\alpha i$ Moîpal) as described in the Respublica X,

${ }^{19}$ Hereinafter Plato's dialogues a cited from: Cooper, Hutchinson 1997.

${ }^{20}$ TP 4.45.21-46.11, Tr. 259-26o.

${ }^{21}$ TP 5.18.18-20, Tr. 310.

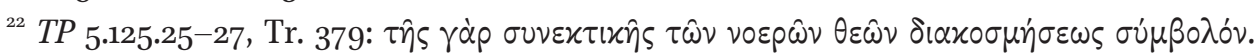

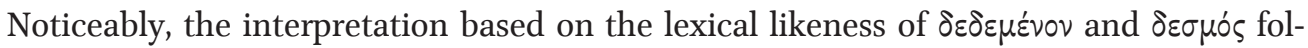
lows one of the methods of Plato's Cratylus and Proclus' commentary on this dialogue (see: Ademollo 2011, esp. pp. 132-138; van den Berg 2008, 173-199; MacIsaac 2013, 97-118). Proclus mentions the Cratylus explicitly several lines above ( $T P$ 5.125.18), where he cites Crat. 404a5-6.

${ }^{23}$ TP 5.91.4-9, Tr. 357 . 
$6 \mathrm{~b}_{7} \mathrm{~b}_{7} \mathrm{~d}_{5}$, are generally named symbols. It is important that before this passage, Proclus discusses the sequence of the Fates, in which they are ordered by Plato. This order is interpreted in detail and is never named symbolical or consisting of symbols. But when Proclus turns to the "sitting on thrones," their location at the "rims" and the "whorls" of the universal "spindle," ${ }^{24}$ he proceeds with a symbolical explanation. Again, if this is not accidental, the order of subjects is immaterial enough to be not considered a symbol as opposed to corporeal material objects. An intentional manner of Proclean wording here agrees with a corresponding synopsis of this chapter 23 in the pinax of the sixth book. ${ }^{25}$

In another place, Proclus speaks about the symbols of a soul's youth, which are "being beardless and having smooth [cheeks] instead of hoariness and beards." ${ }^{26}$ Generally, all the imagery of a human body applied to a soul may be considered symbolic; however, Proclus employs it in his exegesis not often.

According to Proclus, the ascent of the soul to the intellectual realm is accompanied by the "cutting off all the generation-producing symbols" and changing the very eidos of the soul's life. ${ }^{27}$ Probably, this "cutting off" implies the castration of Uranus by Cronus, ${ }^{28}$ as long as Proclus below calls the ascending souls "the nurslings of Cronus." ${ }^{29}$ Thus, in the narrow sense "the generation-producing symbols" are human genitals, which are bodily symbols in the same way, as beards and smoothness of skin above. However, Proclus is speaking about a human soul that does not have genitals as long as any other organs of a body. Thus in the wider sense, this "generation-production" may stand for any becoming, inherent to anything material, while the soul breaking away from the material realm, enters the world of being and ceases any becoming.

However, Proclean wording here does not allow distinguishing, whether all possible symbols are the "generation-producing" ones or these are just one type in a wider variety.

\section{Synthèma as distinguished from symbolon}

In comparison with a symbol, synthèma has a slightly different meaning. Proclus provides us with the following evidence.

\footnotetext{
${ }^{24}$ Respublica X, 616c-617a.

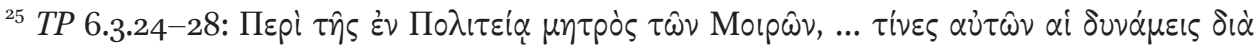

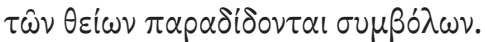

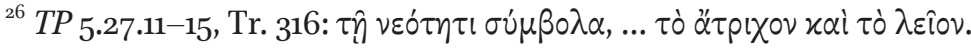

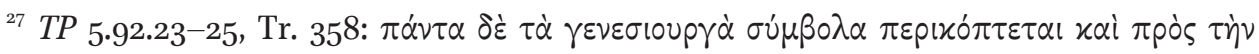

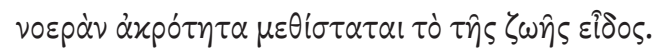

${ }^{28}$ Hes. Theog. $173^{-182 .}$

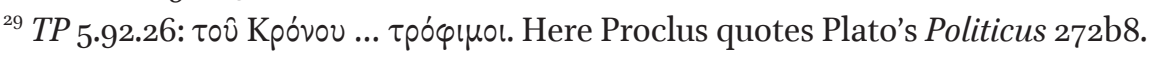


Firstly, there are plenty of examples of particular synthèmata. For instance, "wisdom is a synthēma of Athena and the summit of virtue."30 Among Athena's attributes, Proclus also mentions "rhythm and dance," which are a "mystic synthemma" of her divinity. ${ }^{31}$ Below Proclus says, that "the formless, the indefinite, and the privation of rhythm, are the peculiarities of matter, ${ }^{32}$ and therefore the "rhythm and dance" should be considered properties of the immaterial.

The "cutting off," mentioned in the Timaeus 36 ar ( $\alpha \pi 0 \tau \dot{\varepsilon} \mu \nu \omega \nu)$, is taken as a synthèma also. ${ }^{33}$ In the other place, Proclus says that "the estrangement from the partial, the agility, and the free energy directed to the multiple is a synthema appropriate to the liberated rulers." ${ }^{34}$

A list of different synthēmata is introduced, when Proclus discusses the Parmenides of Plato. The first and the highest point of the intellectual hebdomad is "the father of the intellectual realm," which is followed by "the threefold figure, and the order of the Gods which perfects all things, that which is in itself and in another." According to Proclus, "these things $(\tau \alpha \hat{\tau} \tau \alpha), . .$. are synthemata of the intellectual summit of the intellectual monads." ${ }^{35}$

The paternal intellect is described dually: as the first king and as the father of the intellectual realm, what is interpreted in terms of well-known Neoplatonic triad "unparticipated - participated - participant." ${ }^{36}$ Actually, "being in itself" can be interpreted as an unparticipated rest, and "being in another" as the state of being participated and, consequently, being present in the participant in some way. These two modes are therefore called "a twofold synthemma. ${ }^{37}$ Several pages below Proclus uses a slightly different wording:

\footnotetext{
${ }^{30}$ TP 6.53.8-10, Tr. 425.

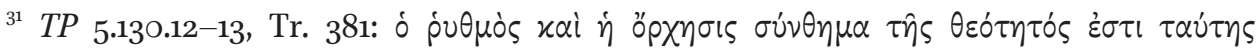
$\mu \nu \sigma \tau i x o ́ v$.

${ }^{32}$ TP $5.130 .17-18$, Tr. 382.

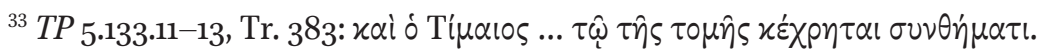

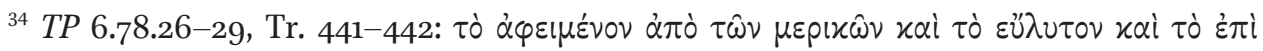

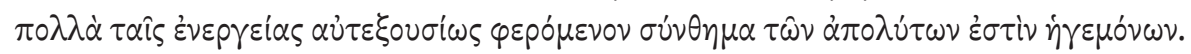

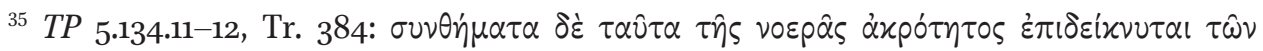

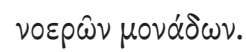

${ }^{36}$ For an introduction into this concept see: Chlup 2012, 18-29 and 99-111.

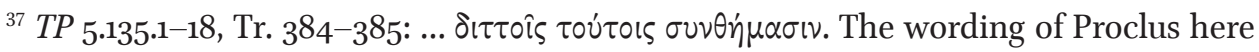
is unclear, but it can be interpreted using a similar formula in his commentary in Timaeum 1.210.11-16: "All things ... both remain in and revert to the gods, receiving this ability from them and obtaining in their very being a double signature ( $\delta 1 \tau \tau \dot{\alpha} \sigma v v \theta \dot{\eta} \mu \alpha \tau \alpha)$, the one in order to remain there, the other so that what proceeds forth can return" (English translation: Runia, Share 2008, 46).
} 
[being] "in another" is the synthēma of the father, [and being] "in itself" is the s y $\mathrm{n}$ th e $\mathrm{m}$ a of the very first unpolluted monad..$^{8}$

In another place, Proclus emphasises the relation of synthèma specifically to the remaining "in oneself:"

being "in another" is the distinguishing property of the intelligible and paternal [levels].... [And being] "in itself" is the proper s y $\mathrm{n} t \mathrm{~h} \overline{\mathrm{e}} \mathrm{m}$ a of the unpolluted monad. ${ }^{39}$

Certain dialectical terms can be synthēmata, such as sameness and otherness: "the same appears to be a synthèma of ... the paternal existence," ${ }^{40}$ and "the term the other is a synthema of a corporeal mode [of being]. ${ }^{m 1}$

Finally, the pinax of the fifth book states that the intermediate intellectual order is described in the Parmenides with the use of synthemata ${ }^{42}$ but there is no more detail on this subject. ${ }^{43}$ Fortunately, the end of chapter 39 contains a full list of all terms, which can be reliably identified with the synthemata, revealed and explained by Proclus in details. They are being in itself and in another, sameness and difference, which can be applied to self and to the other, and all other fundamental predicates exposed in the Parmenides. ${ }^{44}$

More one usage of synthema is given less clearly:

Since the whole order of the assimilative Gods is suspended from the demiurgic monad, subsists about, is reverted to, and perfected by it, it is necessary to refer the $\mathrm{s} y \mathrm{n} \mathrm{t} \mathrm{h} \overline{\mathrm{e}} \mathrm{m}$ a t a of this order to the demiurgic ones, and to give to the former a wellordered generation proceeding in measures from the latter. ${ }^{45}$

In the language of Proclus, monad has a quite exact meaning. In the above-

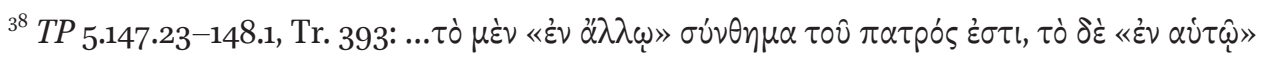

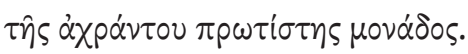

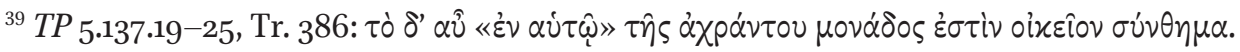

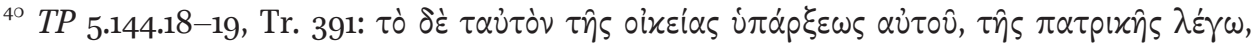

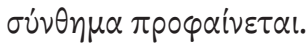

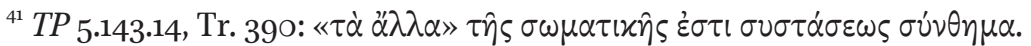

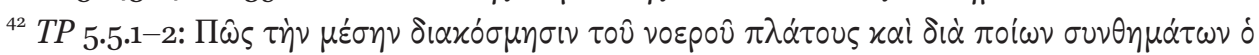

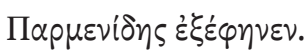

${ }^{43}$ The same happens two more times in the TP: in a pinax Proclus promises to describe "cataphatic synthēmata" of the supercelestial place (TP 4.2.21-23) or the synthema$t a$ of the three hypostases related to it (TP 4.3.1-3), but the corresponding chapters (book 4, chapters 13 and 16 , resp.) mention neither symbolon nor synthēma. One can try to restore from the context, what Proclus could have meant in the pinax, but I could not interpret this text unambiguously.

${ }^{44}$ TP 5.147.22-148.9, Tr. 393.

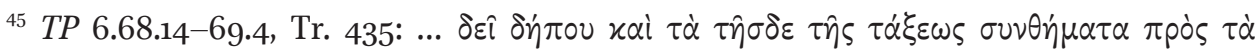

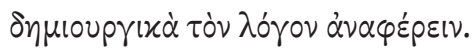


mentioned dialectics of participation, the term monad is related to the unity of unparticipated rest and can be applied to any level of intellectual hierarchy such as the monadic intellect, the monadic soul of the world, and so on down to particular gods.

There are a few more examples of synthemata explicitly related to a monad of one or another layer of the intelligible. ${ }^{46}$ Proclus gives a list of mundane gods, "leaders and rulers in the universe," the angels, daemons, heroes, partial souls, mortals, animals, and even plants - all of them "aspire after their leaders; and in all things, there is a synthema of their proper monad." ${ }^{\prime 7}$ In another place, Proclus says that the specific features of the ruling gods "proceed from the demiurgic monad, and from the synthèmata, which pre-exist there. ${ }^{m 8}$ Also, Proclus once considers a triad of gods as three monads, which have corresponding synthèmata. ${ }^{49}$

\section{Dialectics of symbolon and synthēma}

The main difference between symbolon and synthèma is almost obvious: a symbol is a material object, which makes an intellectual or intelligible substance perceptible, while synthema is anything incorporeal. It may vary from what is the closest to the material world and defines its structure or dynamics, such as "rhythm" and "dance," and up to the most abstract "sameness" and "otherness." However, this is the roughest indication, and if we stop at this point, we will find many instances falling out of this scope.

The most helpful are the places, where $\sigma \dot{v} \mu \beta 0 \lambda$ ov meets $\sigma \dot{v} v \theta \eta \mu \alpha$ in one phrase. The first example of such composition is found in the explanation of the soul's ascent to "the supercelestial place" as it is described in the Phaedrus (247c1 ff.):

the "perfect, and simple, and unshakeable and blissful visions" are revealed to souls supernally "from the supercelestial place," through the holding Gods. For the mystic s y n th è m a t a of intelligible shine forth in that place, and also the unknown and ineffable "beauty of characters." For muēsis and epopteia are a s y m b o l of ineffable silence and the union with mystic natures through intelligible visions. And what is the most admirable of all is this, that as theurgists order the whole body to be buried, except the head, in the most mystic of initiations, Plato also has anticipated this, being moved by the Gods themselves. "For being pure," says he, "and not buried in this

${ }^{46}$ Cf. Valery Petroffs explanation of Proclean synthēmata related to henads, which can be considered monads at the highest ontologic level (Petroff 2013, 220-221).

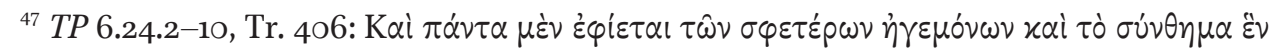

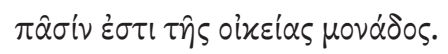

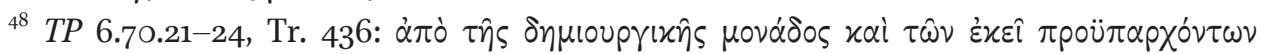
$\sigma \nu \nu \theta \eta \mu \dot{\alpha} \tau \omega \nu$.

${ }^{49}$ TP 6.51.15-18 et 52.14-18, Tr. 424 . 
thing we are carrying around now, which we call a body," we obtained this most blessed muêsis and epopteia, being full of intelligible light. For the "pure shining" $\mathrm{s} \mathrm{y} \mathrm{m} \mathrm{b}$ o l i c a ll y reveals to us intelligible light..$^{50}$

Thus, synthèmata here are mystical visions, which reveal the intelligible realm.

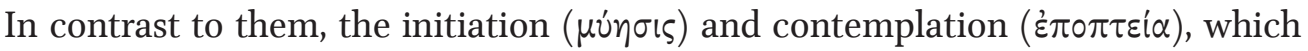
probably refer to Eleusinian mysteries, are considered symbols in the same way as "pure shining" bears symbolical meaning. Both synthèmata and symbola are related to the intelligible, both reveal it to human souls, and both are immaterial. The difference between them, which seems to fit best, is that synthema is directed downwards, as a vision, descended from the divine to human souls, opposed to symbols directed upwards, as initiations and purity, which provide a person with the capability to ascend to the intelligible.

A similar example is given in the discussion of Athena and Curetes, where Proclus tries to agree Orphic theology with what is said about them in Plato's Leges:

Not only Orpheus and the theologists before Plato knew Curetic order, and knowing, venerated it, but the Athenian guest also in the Laws celebrates it. For he says, that "the games in armour of the Curetes" in Crete are the principal paradigms ( $\dot{\alpha} \times \eta \gamma \mid x \dot{\alpha}$

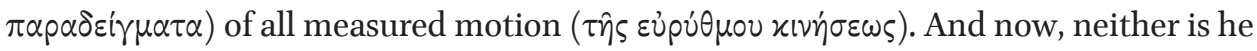
satisfied with having mentioned this Curetic order, but also adds the one henad of the Curetes, namely our mistress Athena.... The Curetes are surrounded above with the $\mathrm{s} y \mathrm{~m} \mathrm{~b}$ o l s of Athena, as presiding over an ever-flourishing life and "vigorous" intellection; but beneath, they are manifestly arranged under the providence of Athena. For the first Curetes, as being the attendants of the intelligible and concealed (xpupias) Goddess, are satisfied with s yn the èm a t a that proceed from thence; but those in the second and third orders, are suspended from the intellectual Athenian monad..$^{51}$

Here a kind if hierarchical relation can be seen: synthèmata pertain only to the first, highest order of Curetes, while the lowest are related to "the intellectual Athenian monad." The symbols as those, which are above, are opposed to "the providence of Athena," which is below. Noteworthy, the relation between the paradigm and its implementations is given separately, and thus probably should be confused neither with symbolic, nor synthematic dependencies.

The "upper" position of both symbols and synthèmata makes it difficult to distinguish them. Proclean wording allows treating these terms as complete synonyms in this passage. But several lines below Proclus gives a more distinctive commentary:

\footnotetext{
${ }^{50}$ TP 4.30.9-31.1, Tr. 250 .

${ }^{51}$ TP $5.128 .5^{-21}$, Tr. 38 o.
} 


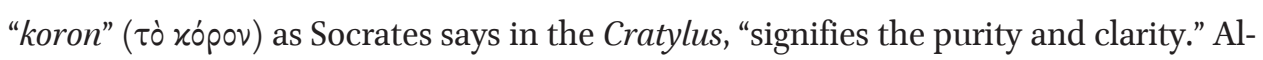
so, the Curetes are allotted their appellation, as presiding over the undefiled purity of the Gods. And the monad of them is particularly celebrated as "a mistress and as Core," as she is the leader of an inflexible and flourishing dominion to the Gods. The word "koron" therefore, as we have said, is a sy m b o l of purity, of which these Gods are the primary leaders, and according to which they are participated by others ( $\dot{v} \pi \dot{\partial} \tau \hat{\omega} \nu \alpha \ddot{\alpha} \lambda \omega \omega \nu \mu \varepsilon \tau \dot{\varepsilon} \chi 0 v \tau \alpha \mathrm{l}$ ). And their "armament" is a s y $\mathrm{n} \mathrm{t} \mathrm{h} \overline{\mathrm{e}} \mathrm{m}$ a of the guardian power according to which they connect wholes, guard them exempt from secondary natures, and preserve them established in themselves. ${ }^{5^{2}}$

Here symbolon and synthèma are involved in the dialectics of participation: synthèma stands for the unparticipated level, and participation is made possible via symbols. However, both symbols and synthēmata are imparted from a higher ontological level (here it is Athenian monad related to lower gods), but obviously, this is an implementation of a more general scheme. Thus, here is no contradiction with the previous quotations, where synthema is related to participation: both symbol and synthèma originate from participation to a higher level, but then synthèma keeps the current, participating level in its remnant state, i.e. unparticipated, while a symbol allows this participating level to be participated itself. Probably, the "ever-flourishing" can be understood as a "visible," i.e. participated form of life expressed through a symbol, as opposed to the "concealed," i.e. unparticipated character of Athena, which is expressed with a synthema in the previous quotation.

A more difficult passage is connected with the Oracula Chaldaica, fr. 108 (des Places), one of the most favourite places by Proclus, which he cites many times in his writings. Noteworthy, here Proclus intentionally replaces the original

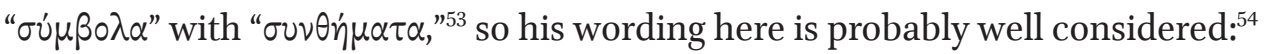

[That, who is] the cause of all, "disseminated in all things" the s y n th e e m a t a of his perfect supremacy, and through these, he establishes all things about himself, and being exempt from the whole of things, is ineffably present everywhere. Therefore, everything entering into the ineffable of its own nature finds there the $\mathrm{s} \mathrm{y} \mathrm{mbol}$ of the Father of all. All things venerate him according to its nature and are united to him through an appropriate mystic s y $\mathrm{th} \overline{\mathrm{e}} \mathrm{m}$ a, divesting themselves of their nature,

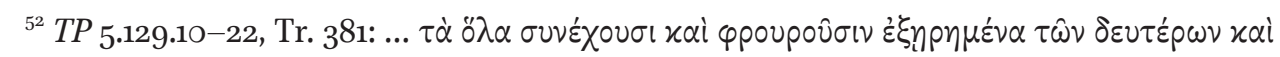

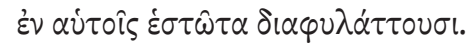

${ }^{53}$ The term synthèma is present in the Oracula twice; one of the instances is in the fr. 109, just a few lines below.

${ }^{54}$ A similar substitution is done in the commentary in Cratylum 71.18-20: oi $\pi \alpha \tau \varepsilon \dot{p} \varepsilon \varsigma$

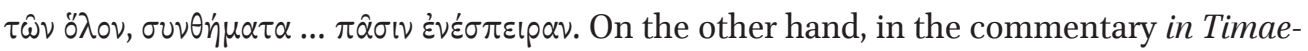

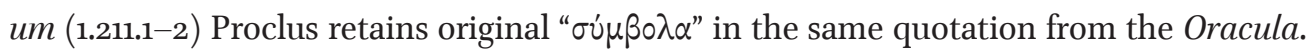


and hastening to become only his syn thē ma, and to participate only in him, through the desire of his unknowable nature, and of the spring of good. ${ }^{55}$

The difference between synthèma and symbolon in the first half of the passage may be expressed as follows: the synthēma is what is "disseminated," or planted by the "Father of all," and the symbol is what is found by the inferior beings. In other words, synthēmata here stand for a core or invisible substance, which is revealed or discovered as a symbol.

Nonetheless, the synthèma as an ontological "root" of a symbol can be eventually reached, but it remains "mystic," or in some way ineffable. Finally, the being, which found a symbol and reached the "mystic synthèma," can become a Father's synthèma itself, what is thought to be a uniting with him and participation in his being.

Again, synthèma is closely related to the dialectics of participation, while symbolon acquires a dependent and secondary role as an expression or revelation of synthèma. Thus, synthèma should have an essential nature, while symbolon may be less ontologically stable. Here we can conclude that the first distinct feature of synthema is its representative function,$^{56}$ as it reveals the upper ontological level inside the lower, and performs it as a form of participation in the upper, but not making the lower participated on its side.

\section{Numeric symbols}

This instability may be illustrated by a noteworthy group of examples. Above, we have seen that a symbol is primarily a corporeal object as opposed to an immaterial synthēma, which can be a dialectical notion, a part of the intellectual realm, or an attribute of soul or intellect. But there is one exception: numbers, ratios between parts of a whole, measurable parts of time and space are always symbols and never synthèmata in the TP.

For example, twelve ( $\dot{\eta} \delta \cup \omega \delta \varepsilon x \alpha \dot{\zeta}$ ) as a number of gods is "a symbol of perfect progression. ${ }^{57}$ Here Proclus emphasises: "this number must not be surveyed as if it was such as twelve is in units (for a number in the Gods is not of this kind), but [it must be beheld] in the peculiarity of subsistence. ${ }^{.58}$

The primary key to understanding this saying is the Neoplatonic doctrine of

${ }^{55}$ TP 2.56.16-26, Tr. 161.

${ }^{56}$ Here I follow the wording of Peter Struck 2004, 234. However, he does not distinguish symbolon from synthema and therefore applies this function to both of them.

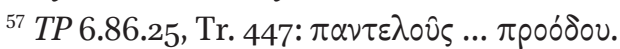

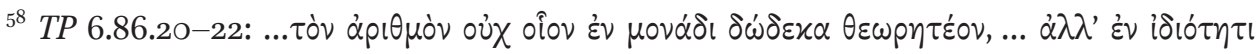

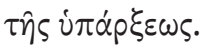


ideal numbers, explicitly given by Plotinus in the Enneades VI, 6 (34), the treatise named On numbers by Porphyry. ${ }^{59}$ Plotinus introduced a difference between ideal and monadic, or countable numbers (Enn. VI.6.9.31-37). Ideal numbers are uncountable; there is no progression or shift from one ideal number to another through adding or subtracting any other number. Thus, the quantitative characteristic of an ideal number is actually its main quality (another quality of every number is its unity, and from this standpoint, every ideal number is a henad, see: Enn. VI.6.11). On the opposite, monadic numbers are countable; they are subject to arithmetical operations and are very close to our ordinary conception of number in mathematics. Finally, the monadic number is considered an unclear image ( $\varepsilon i \delta \omega \lambda \circ v)$ of an ideal number, compared to a material object related to its idea ( $\varepsilon \hat{\delta} \delta \circ$ ). The ideal number is described in comparison with the "base, spring, root, and origin" of what follows it. ${ }^{60}$

Probably, the "peculiarity of subsistence," mentioned by Proclus, expresses the qualities of an ideal number as opposed to a sum of monadic "units." Noticeably, this "root and origin" of being is called symbol, not synthêma, what could be expected in the vein of an essential and intrinsic sense of the latter. An explanation can be found again in the On numbers: Plotinus states that an ideal number precedes any being, ${ }^{61}$ and thus is excluded from any ontological predication. ${ }^{62}$ Probably for Proclus, the essential nature of synthèma could not be harmonised with such an un-ontological number, and therefore the term symbolon is employed.

In the TP book 4, chapter 29, Proclus gives his dialectics of numbers, which is expressed in a complicated manner that is difficult to interpret without the Plotinian background. Firstly, Proclus separates the primary henads from numbers, even at the highest level. Nonetheless, they can be considered either supersub-

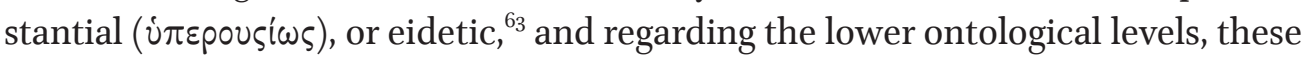
numbers produce their individual hierarchy, from the intellectually-intelligible order, through pure intellectual, and supercelestial down to sublunary ones. ${ }^{64}$

\footnotetext{
${ }^{59}$ Vita Plotini, $5 \cdot 35$.

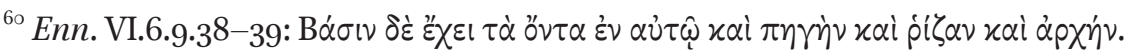

${ }^{61}$ Enn. VI.6.9.12-13: "The One precedes being, and the number precedes beings

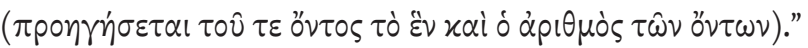

${ }^{62}$ However, this is the highest modus of an ideal number, as long as it precedes being,

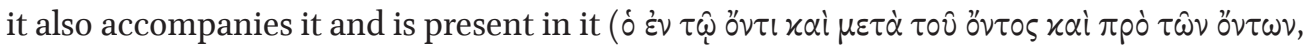
Enn. VI.6.9.35-37).

${ }^{63}$ TP 4.88.20-21, Tr. 286.

${ }^{64}$ TP 4.86.1-19, Tr. 284-285.
} 
Mathematical (countable) numbers pertain to the lower orders in this scheme. ${ }^{65}$ However, the numerical hierarchy remains separated from the hierarchy of beings and therefore may be called ontologically irrelevant.

Probably, such ontologically irrelevant meaning of a symbol is implied by Proclus when he speaks of "the parts of time" as the "symbols of encompassing according to cause, ${ }^{n 6}$ or of "the direct" that is "a symbol of progression. ${ }^{n 67}$ A more complex combination of Plato's imagery is built around the hebdomadic division of the circles in the soul and corresponding orders of gods: all of them contain sevenfold structure and thus are called "symbols of assimilative, ... and of the liberated gods. ${ }^{\prime 68}$ Finally, the abovementioned chapter 29 is referred in the pinax of book 4 as explaining "how divine number adorns all beings, and what the powers in it are which are symbolically delivered from the division of number. ${ }^{\prime 69} \mathrm{Howev}$ er, the chapter text itself does not use the term symbolon at all.

Thus, the second distinctive feature of a synthema is its ontological status, i.e. its essential nature as opposed to a symbol, which can be excluded from any ontological predication.

\section{Synthèma as a means of knowing the intelligible}

Another role of synthèma in Proclean metaphysics is related to the problem of cognition of the highest ontologic layers. Firstly, Proclus says about the "order, which is the summit of the intellectual Gods," that it is

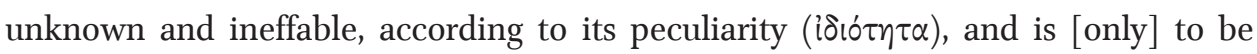
known through intelligible s y $\mathrm{n} \mathrm{th} \overline{\mathrm{e}} \mathrm{m}$ a t a. For being the summit of the intellectual, it conjoins itself with the intelligible. ${ }^{70}$

Several lines below, Proclus adds:

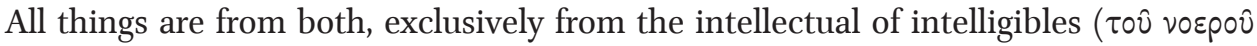

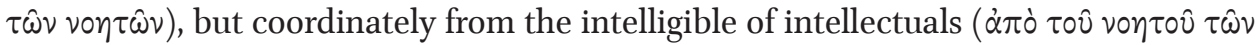

\footnotetext{
${ }^{65}$ Proclus provides general reasoning about the place of mathematical knowledge and mathematical objects related to the universal intellect and the soul (see: O'Meara 2017, 172-175 and references to relevant Proclus' works there).

${ }^{66}$ TP 6.105.7-8, Tr. 459 .

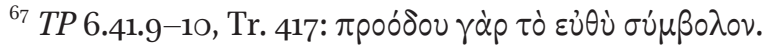

${ }^{68}$ TP 5.19.24-20.9, Tr. 311.

${ }^{69}$ TP 4.4.11-13.

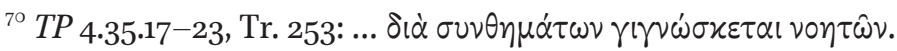




\section{On symbolon and synthema in Proclus}

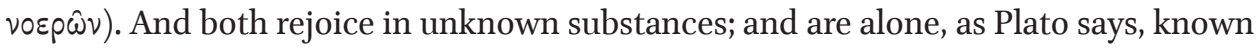
by intelligible, mystic, and ineffable s y $\mathrm{t} \mathrm{h} \overline{\mathrm{e}} \mathrm{m}$ a t a. ${ }^{71}$

In other words, synthêmata are the means (possibly, the only means) for the inhabitants of the lower ontological levels to know the upper level. Of course, these synthèmata are not "hidden" in the upper level, but are present among the lowers as a "messenger" or an "evidence" of what is otherwise ineffable and thus unknowable. However, synthēmata themselves are not sufficient to provide such kind of knowledge. In another place, Proclus provides a more detailed description: he says that "the middle order ( $\mu \varepsilon_{\sigma} \eta \delta$ เ $\alpha$ xó $\left.\sigma \mu \eta \sigma \iota \varsigma\right)$ " as a whole is

vivific, connective and perfective ( $\tau \varepsilon \lambda \varepsilon \sigma 10 u p \gamma o ́ \varsigma)$. But the summit of it reveals the s y n the e mat a of the intelligible and its ineffable unity. Its lowest [level] reverts ( $\dot{\varepsilon} \pi \sigma \tau \rho \dot{\varepsilon} \varphi \varepsilon l)$ the intellectual, and conjoins it to the intelligible. And the middle, like a "centre," collects into, and fixes in itself the whole genera of the Gods. ${ }^{72}$

Another well-known Neoplatonic triad of Proclus is "remaining ( $\mu$ ov $\left.\eta^{\prime}\right)$ - pro-

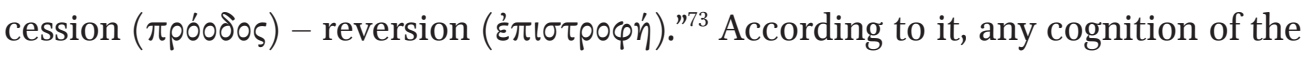
upper level should be performed as some kind of reversion ( $\dot{\varepsilon} \pi \sigma \tau \rho \varphi \eta \dot{)}$. Therefore, the presence of a synthema, which reveals the upper, "ineffable" level, should be accompanied by the epistrophic approach of the cognizant.

Finally, not only the highest levels of the intelligible are ineffable, but the Demiurge of Plato's Timaeus is also considered inconceivable to some extent:

If someone recollecting what is said in the beginning of the Timaeus about him [the Demiurge], i.e. that "it is difficult to discover him," and "when found, impossible to speak of him to all men," should enquire in the first place, why since the Greek theology ascribes such a name to the Demiurge, as we have before mentioned, Timaeus says that he is ineffable, and established above all the indication which exists in

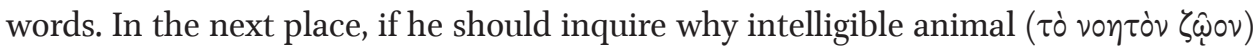
which is arranged above the Demiurge is both denominated and is made known by many s y n thē mat a, but the Demiurge who has established his kingdom in an order secondary to that of all-perfect animal ( $\left.\tau \circ \hat{v} \pi \alpha \nu \tau \varepsilon \lambda \circ \hat{\varsigma} \varsigma \zeta \hat{\omega}^{\prime} \circ \nu\right)$, and is an intellectual God, ... is left by Timaeus ineffable, as we have said, and unknown. ...

For when he says that "it is impossible to speak of him to all men," he does not leave him entirely ineffable and unknown. And the assertion that "it is difficult to discover" him, is the s y $\mathrm{n} t \mathrm{~h}$ e $\mathrm{m}$ a of his peculiarity to be not wholly unknown. For because the Demiurge has established a kingdom analogous to the Good, but in second-

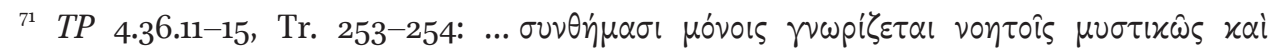

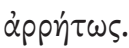

${ }^{72}$ TP 4.26.20-27.1, Tr. 247-248.

${ }^{73}$ On this triad in Proclus' philosophy and some its sources see: Gersh 1973, 49-53; Chlup 2012, 64-69. 
ary and manifold orders of it, he participates the s y n th è m a t a of the Good, but is allotted the participation in conjunction with an appropriate peculiarity, and a communion with beings adapted to him. ${ }^{74}$

Different instances of synthèmata mentioned here provide us with the following: firstly, the "intelligible animal" is expressed via synthêmata at lower levels, among which is the Demiurge as well. Secondly, the Good has also proper synthèmata distributed among different intelligible and intellectual levels. These highest instances are at least to some extent ineffable ${ }^{75}$ and are known through the participation in them by the lowest beings that join proper synthemata or even discover them inside themselves. Finally, the synthemata may be produced not by the generating (upper-level) substance itself, but its certain essential property ("peculiarity"). However, the knowledge of this property brings to the participation in the upper substance as a whole.

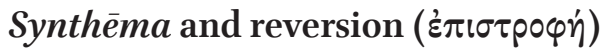

The knowledge, acquired with the means of synthemata accompanies the theurgic ascent to the highest levels of the intelligible realm. Proclus provides just a few but quite distinct clues of the perfective role of a synthema:

The supercelestial place is the first triad of the intelligible and at the same time intellectual Gods. ... It receives in itself the plenitude of forms ( $\tau \dot{\delta} \pi \lambda \dot{n} \rho \omega \mu \alpha \tau \hat{\omega} \nu \varepsilon \dot{\delta} \delta \hat{\omega} \nu)$ from the intelligible paradigms and produces its own "meadow" from the fontal summit which is there. From the one intellect it gives existence ( $\dot{\tau} \pi \circ \sigma \tau \dot{\eta} \sigma \alpha \sigma \alpha)$ to the three virtues, perfects everything by intelligible s y $\mathrm{th} \overline{\mathrm{e}} \mathrm{m}$ a ta, and in its ineffable "bosoms" ( $\left.x^{\prime} \lambda \pi \circ \varsigma\right)$ receives the whole of intelligible light. ${ }^{76}$

The dialectics of reversion is developed here in a new direction: a synthēma of an upper substance being present at the given level allows it to ascend to its origin on a way of return, ascend, and perfection. Noteworthy, the "perfection," $\tau \varepsilon \lambda \varepsilon^{i} \omega \sigma \iota \varsigma$ as derived from $\tau \dot{\varepsilon} \lambda$ ○५ also implies movement to the final aim, complete fulfilment, maturity, and therefore cease of linear motion. ${ }^{77}$ Once again Proclus

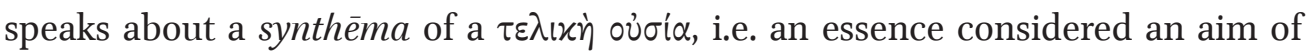

\footnotetext{
${ }^{74}$ TP 5.102.12-24 et 104.21-28, Tr. $364-365$.

${ }^{75}$ Even the Good itself may be described as a cause related to its consequences, e.g. as a cause of various particular goods.

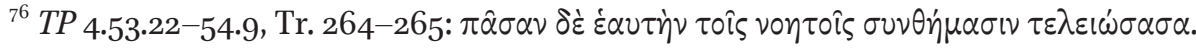

${ }^{77}$ Linear, circular, and mixed (spiral) motions pertain to different levels of the intelligible realm, for details see: Stamatellos 2007, 131-133. The same triad in terms of limit, unlimited, and mixed is discussed in: Gersh 2014, 84-89. Both triads are briefly mentioned in the TP 4.111.17-112.2, Tr. 301.
} 
ontologic progression. ${ }^{78}$

Finally, the supercelestial place is said to be

without colour, without figure, and without contact. However, it transcends these three not privatively, but according to causal excellence. For it imparts to colour from intelligible the participation of light; on figure it confers by illumination an intellectual bound; and in contact it supernally inserts union and continuity, and perfects all things by its power; things which are touched - through union, those that are figured - through the participation of bound, and those that are coloured — through the illumination of light. It draws upward, and attracts to itself everything ineffably with the means of intelligible sy n the e mata, and fills everything with unitary goods. ${ }^{79}$

It is important to emphasise that it is the supercelestial place itself that is "drawing up" the lower ontological level, and the corresponding synthèma is just an instrument that provides the possibility of such an ascent. Of course, this does not contradict to what is said above but is just a view from another standpoint at the same dialectics of procession and reversion. The reversion in Proclus has two complementary sides: on the one hand, the upper essence that proceeds down to a lower level then returns at the epistrophic phase to its original resting state; and on the other hand, the epistrophic phase means the ascent of the newly generated (lower) instance to its "parental" origin. ${ }^{80}$ Thus synthèma may be considered from the standpoint of the "parental" and the "offspring" levels, and these two variants have been presented above.

Anyway, the third distinct feature of a synthēma is its epistrophic or anagogic function, closely related to the dialectics of procession and reversion.

\section{Ineffable and anagogic symbols}

However, the anagogic ${ }^{8_{1}}$ and "mystical" character pertains not to synthèmata only, but to symbols as well. Firstly, Proclus speaks about the "ineffable symbols" known to the highest gods, but incognizable by the mortals (however, incognizable here does not mean completely unapproachable):

You may see the order of things, and the remission in them proceeding in a downward progression. For the Good is exempt from all silence, and all language. But the genus of the intelligible Gods rejoices in silence and is delighted with ineffable

${ }^{78}$ TP 5.83.12, Tr. $35^{2}$.

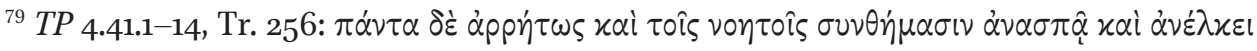

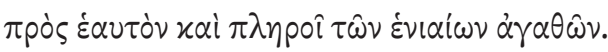

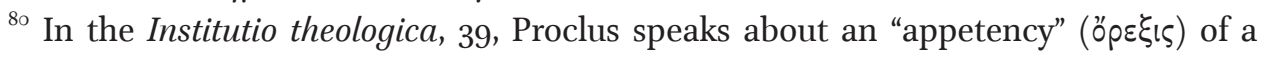
lower substance for the reversion to its cause.

${ }^{81}$ This term is used according to how it is understood by P. Struck 2004, 248-252. 
s y m b o l s. Hence, also Socrates in the Phaedrus calls the vision of the intelligible monads the holiest initiations, as being involved in silence, and perceived intellectually in an arcane manner. But the vision of the intellectual is effable, yet is not effable and known to all men, but is known with difficulty. ${ }^{82}$

The notion of "ineffable symbol" is somehow self-contradictory as all the symbols discussed above were capable of expressing anything, and the expression implies the availability of what is expressed to some observer. Ineffability here has two grades: firstly, what is inconceivable for mortals, may be available for pure intellects, and secondly, after Iamblichus, Neoplatonic theurgy knows words, phrases, certain symbols that cannot be understood with the means of reason, but carry simple and united intelligible meaning (cf.: Iamblichus, De mysteriis 7.4.5-21).

Above we have met synthèmata related to unparticipated being in oneself and symbola related to participation and being in another; but when considering a "mystical" type of symbols, Proclus provides an example of an unparticipated symbol that keeps the being in oneself from relations with the lower:

union is ... derived to all things, from the first unity, which is exempt from all multitude, and all division. But in consequence of their [i.e. supercelestial Gods'] having pre-assumed the power of touching themselves, according to the being in self, they derive their existence from the unpolluted Gods. For the being in self in the first of the intellectual fathers, was the s y $\mathrm{m} \mathrm{b} \mathrm{ol} \mathrm{of} \mathrm{an} \mathrm{invariable} \mathrm{cause,} \mathrm{and} \mathrm{which} \mathrm{immu-}$ tably sustains multitude from secondary natures. ${ }^{8_{3}}$

The hierarchy of unity, which on the way downwards from the One changes to multiplicity, can be paralleled with the hierarchy of effability that increases on the same way. The more multiple, partial, and complex an essence is, the more it is subject to verbal expression and rational knowledge. The "intellectual fathers" remaining in themselves and thus symbolising the "invariable cause," are placed at one of the highest levels of this hierarchy, where symbols remain only relatively effable, as is explained concerning the previous quotation. Such symbols cannot be completely grasped by human reason. However, if there is any possibility for a mortal to approach them, it should be done supra-rationally, in a "hypernoetic" way. ${ }^{84}$

Finally, as synthèmata could have the epistrophic function, Proclus ascribes a

\footnotetext{
${ }^{82}$ TP 5.105.3-11, Tr. 366.

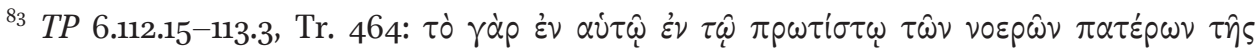

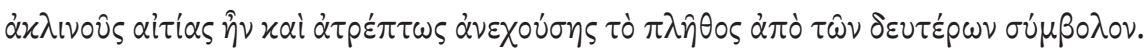

${ }^{84}$ Here I follow the terms of Tuomo Lankila (2010). Cf. relevant sayings of Proclus: TP 4.31.12-16; in Crat. 71.98-103.
} 
similar activity to symbols as well:

There is a twofold reversion in those orders, the one being towards themselves, but the other towards the causes of them.... And the intelligible Gods generate all things stably; but the intelligible and intellectual Gods, who illuminate imparticipable life, impart the original cause of progression to all things; and the intellectual Gods arrange and adorn wholes according to reversion. Hence, it is necessary that the summit of the intellectual, which pours forth from itself the whole and perfect form of reversion, should be characterised by both the reversal sy mbols, and should be at the same time reversed to itself and the natures prior to itself. ${ }^{85}$

It is not clear, what exactly is understood here by the "reversal symbols." Most probably, it is being in oneself and being in another, as it follows from the discourse of the Parmenides that is discussed in the chapter quoted, and from the similar passages in other places of the $T P$, many of which, as we have seen, contain frequent uses of $\sigma \dot{v} \mu \beta 0 \lambda \propto v$ and $\sigma \dot{v} v \eta \eta \mu \alpha$.

Another problem that arises, when epistrophic symbols are considered, is that these symbols are intelligible, i.e. absolutely immaterial. The only exclusion for the rule of symbol's materiality, which we have met yet, was related to the numerical symbolism. Now it should be added that a symbol can be intelligible. However, it is not clear how substantial it is, i.e. does it have the same essential nature as an intelligible synthèma, or not?

As a clue, one can refer to the supercelestial light of Helios, which is said to be "similar to none of the others; nor does he receive this light from the subject matter, but himself produces and generates it from himself, and extends ... a symbol of intellectual essences" ${ }^{86}$ If this immaterial light can be set analogous to the illumination- $-\varepsilon \lambda \lambda \alpha \mu \psi(\varsigma$, then this particular symbol is not an autonomous essence, and a more proper name for it should be energy (in Aristotelian sense). As regards synthèmata, they are always substantial and incorporeal, what makes a difference to symbols of any kind — material, numerical, or intelligible.

\section{Conclusion}

Comparing symbolon and synthēma in the $T P$, the following distinctive features can be outlined:

— a synthèma is directed downwards, it is "disseminated," "planted," or in any other way hidden in the being; a symbol is directed upwards, it is found, or "dis-

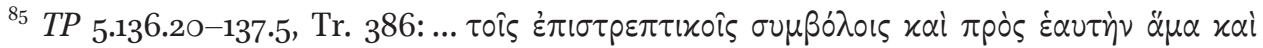

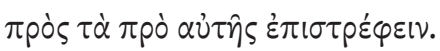

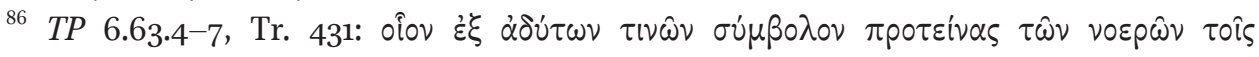

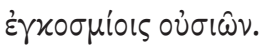


covered" in the being;

- a synthema is an inner kernel of what is discovered as a symbol, and a symbol is an outward expression of a synthèma;

- any synthèma has substantial nature, while a symbol can be excluded from any ontological predication, or be compared with an energy of a substance;

- synthèma in an object keeps it on an unparticipated level, while a symbol makes a symbolic object capable of being participated. However, both synthèma$t a$ and symbola are produced as a result of participation to a higher level. They differ only by the form of secondary (un)participation on the lower, participating level;

- both synthemata and symbola are related to the dialectics of reversion. However, a synthèma is responsible for the knowledge of intelligible, while a symbol is related to the hypernoetic grasping of what is ineffable;

- a synthema is always immaterial: it is a notion, a structure, or a property of the intellectual or intelligible realms. A symbol may be either a material object or something incorporeal, which can have ontologic predicates (intelligible symbols) or be ontologically irrelevant (numeric symbols).

Finally, symbols in the TP can be ordered in four groups:

- theurgic symbols, which are material objects, available for theurgic rites and perceptible by any human;

- exegetical symbols, which are literal descriptions of material objects; they also may have theurgic power, but are perceived only rationally;

- ontologically irrelevant symbols, such as numbers, ratios, distances, parts of time and space;

- "ineffable" symbols, which are entirely unavailable to humans or available only to the highest noetic level of human intellect.

On the contrary, synthèmata are uniform; all of them have common properties and cannot be divided into groups. Therefore, they may be considered as the universal "token" testifying the belonging to the primary essence ( $\left.\tau \varepsilon \lambda \iota x \dot{\eta} \circ v^{\circ} \boldsymbol{i}^{\alpha} \alpha\right)$ of every being caused by it. In terms of Proclean dialectics of causal "series," a synthèma may be understood as a specific "footprint" of the first cause in all its consequences. ${ }^{87}$ A synthema is what guarantees the invariance and stability along the way of ontologic hierarchy getting evolved. The symbols, on their part, reveal the corresponding synthēmata in a changeable way, getting "adjusted" to every corresponding ontologic level.

\footnotetext{
${ }^{87}$ Cf. Petroff 2O13, 211-212.
} 


\section{REFERENCES}

Ademollo, F. (2011) The Cratylus of Plato. A commentary. Cambridge: Cambridge University Press.

Benveniste, É. (1966) «Problèmes sémantiques de la reconstruction», É. Benveniste, Problèmes de linguistique générale, 1. Gallimard, 289-307.

Berg, R.M. van den (2008) Proclus' Commentary on the Cratylus in context: Ancient theories of language and naming. Leiden, Boston: Brill.

Cardullo, R.L. (1985) Il linguaggio del simbolo in Proclo: Analisi filosofico-semantica dei termini symbolon / eikôn / synthêma nel Commentario alla Repubblica. Catania: Università di Catania.

Casaglia, M., Linguiti, A., tr. (2007) Proclo. Teologia Platonica. Torino: UTET.

Chlup, R. (2012) Proclus. An introduction. Cambridge: Cambridge University Press.

Cooper, J.M., Hutchinson, D.S., eds. (1997) Plato. Complete works. Indianapolis, Cambridge: Hackett Publishing Company.

Dillon, J. (1975) "Image, symbol, and analogy: Three basic concepts of Neoplatonic exegesis," R. Baine Harris (ed.), The significance of Neoplatonism (Studies in Neoplatonism 1). Norfolk, VA: International Society for Neoplatonic Studies.

Festugière, A.-J., tr., éd. (1966-1968) Proclus. Commentaire sur le «Timée», liv. 1-5. Paris: J. Vrin.

Gersh, S. (2014) "Proclus as theologian," S. Gersh (ed.), Interpreting Proclus: From Antiquity to the Renaissance. Cambridge University Press, 80-107.

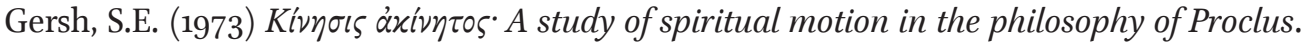
Leiden: Brill.

Kurdybaylo, D.S. (2019) “On symbolism in Proclus' Commentary on Plato's Timaeus," The Philosophy Journal 12.2, 144-159 (in Russian).

Kurdybaylo, D.S. and I.P. (2018) "Ontology of name and naming in Proclus' Commentary on Plato's Cratylus," Platonic Investigations 8/1, 86-124 (in Russian).

Lankila, T. (2010) "Hypernoetic cognition and the scope of theurgy in Proclus," Arctos: Acta Philologica Fennica 44, 147-170.

MacIsaac, D.G. (2013) "Proclus: philosophy as the exegesis of 'sacred' texts," T. Kirby, R. Acar, and B. Baş (eds.), Philosophy and the Abrahamic religions: Scriptural hermeneutics and epistemology. Newcastle upon Tyne: Cambridge Scholar Publishing, 95-134.

O'Meara, D. (2017) "Mathematics and the sciences," P. d'Hoine, M. Martijn (eds.), All from One: A guide to Proclus. Oxford: Oxford University Press, 167-182.

Petroff, V.V. (2013) "Symbola and synthemata in the theurgical Neoplatonism of Iamblichus and Proclus," V.V. Petroff (ed.), Platōnika zētēmata. Studies in the history of Platonism. Moscow: Krug, 210-225 (in Russian).

Rappe, S. (2007) Reading Neoplatonism: Non-discursive thinking in the texts of Plotinus, Proclus, and Damascius. Cambridge: Cambridge University Press.

Runia, D.T., Share, M., eds., trs. (2008) Proclus. Commentary on Plato's Timaeus. Vol. II, 


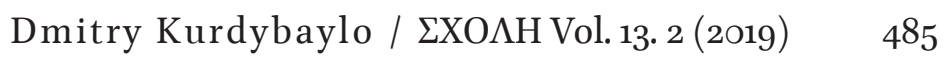

Book 2. Cambridge: Cambridge University Press.

Saffrey, D., Westerink, L.G., tr., ed. (1968-1997) Proclus. Théologie platonicienne, vols. 1-6. Paris : Les Belles Lettres.

Shaw, G. (1995) Theurgy and the Soul: The Neoplatonism of Iamblichus. University Park, PA: The Pennsylvania State University Press.

Sheppard, A. (2014) "Proclus as exegete," S. Gersh (ed.), Interpreting Proclus : From Antiquity to the Renaissance. Cambridge University Press, 57-79.

Sheppard, A.D.R. (1980) Studies on the $5^{\text {th }}$ and $6^{\text {th }}$ Essays of Proclus' Commentary on the Republic. Göttingen: Vandenhoeck und Ruprecht.

Stamatellos, G. (2007) Plotinus and the Presocratics: A philosophical study of Presocratic influences in Plotinus' Enneads. Albany, NY: State University of New York Press.

Struck, P.T. (2004) Birth of the symbol: Ancient readers at the limits of their texts. Princeton, Oxford: Princeton University Press.

Tarrant, H., ed.; Duvick, B.M., tr. (2014) Proclus. On Plato Cratylus, $2^{\text {nd }}$ ed. London, New Delhi, New York, Sydney: Bloomsbury.

Taylor, Th., tr. (1995) Proclus. The Theology of Plato. Frome, Somerset, UK: The Prometheus Trust.

Trouillard, J. (1972) L'un et l'âme selon Proclos. Paris: Les Belles Lettres.

Trouillard, J. (1974) «L'activité onomastique selon Proclos», H. Dörrie (éd.), De Jamblique a Proclus. Genève : Vandœuvres, 239-251.

Trouillard, J. (1981) «Le symbolisme chez Proclos», Dialogues d'histoire ancienne 7, 297308.

Turolla, E., tr. (1957) Proclo, La teologia Platonica. Bari: Editori Laterza. 